\title{
The Arendtian Dread: Courts with Power
}

\author{
Or Bassok ${ }^{\circ}$ \\ [forthcoming in Ratio Juris].
}

\begin{abstract}
Hannah Arendt was fearful not only of a populist President speaking in the name of the people and unbound by legality. She was also concerned that the popular will could be harnessed to support those responsible for limiting it. More concretely, she was fearful of the American Supreme Court relying on popular support. This is the meaning behind her obscure depiction of the American Supreme Court as "the true seat of authority in the American Republic" but as unfit to power. I argue that Arendt's characterization of authority as requiring "neither coercion nor persuasion" means that the Court's source of legitimacy is expertise rather than public support. Yet the current dominant understanding among American Justices as well as scholars is that public support is the source of the Court's authority. In Arendt's mind, such an understanding means that the Court has become the seat of power. The corruption of the Court's authority and constitutional law as a language of expertise capable of resisting public opinion will inevitably follow. Arendt would thus be extremely concerned by the continuing erosion in understanding of the American Supreme Court as an expert, and from the rise of the understanding that its source of legitimacy lies in public confidence.
\end{abstract}

\section{Introduction}

Hannah Arendt would view the current reading of The Federalist No. 78 by Americans, and especially Supreme Court Justices, as capturing the source of the crisis in which American constitutional law is currently in. In recent decades The Federalist No. 78 has been paraphrased in the writings of the Justices of the American Supreme Court (hereinafter: the Court), legal scholars and political scientists (Bassok 2016; Bassok 2013, 159-61), without even noticing they are changing its original meaning. Americans now read The Federalist No. 78 to say that without the sword or the purse all the judiciary has is public confidence (see, e.g., Republican Party of Minnesota v. White, 536 U.S. 765, 817-18 (2002) (Ginsburg, J., dissenting); Gibson, Caldeira,

\footnotetext{
- Assistant Professor at the School of Law of the University of Nottingham. I am grateful to Mikael Madsen, Marlene Wind, and Juan Mayoral for two generous invitations to the iCourts Centre at the University of Copenhagen without which this paper would not have been written. I presented earlier drafts at the Trust, Social Capital and Networks workshop at iCourts, the Max Weber Tenth Anniversary Conference and the 2017 I-CON Conference. Marina Aksenova, Richard Bellamy, Filipe Bastos Brito, Shai Dothan, Dana Schmalz, and Achilles Skordas offered valuable comments and assistance. All errors are my own.

This article may be used for non-commercial purposes in accordance with Wiley Terms and Conditions for SelfArchiving.
} 
Baird 1998, 343; Karlan 2012, 71). In The Federalist No. 78, Hamilton wrote that without the sword or the purse all the judiciary has is merely judgment. Arendt read Hamilton correctly: for her, the Court's reliance on its legal expertise rather than on public support was crucial for the survival of the American Republic. In her terms, in order for the American Republic to survive, the Court must rely on its authority (expertise in interpreting the Constitution) and not on power (public support).

This article offers three insights on Arendt's reading of the American Supreme Court. First, I use Arendt's reading of The Federalist No. 78 to show that the current prevailing reading of Hamilton's dictum on the source of the Court's legitimacy is not merely an innocent paraphrasing of Hamilton's idea. Rather, it represents a major shift in understanding judicial legitimacy in the US. Second, I explain Arendt's fear of a court with power as the fear of a court that understands its source of legitimacy in public support. This point has not received any attention in scholarly literature thus far. Third, while Arendt's major fear was of uninhibited power - in the sense of public will unbound by any limitations - her writings also expose a fear of corrupted authority. Arendt was thus fearful not only of a populist President speaking in the name of the people, unbound in fulfilling popular will. She was also concerned that popular will could be harnessed to support those responsible for limiting it. Based on this insight, I suggest that Arendt would be extremely concerned by the continuing erosion in understanding the American Supreme Court as an expert, and from the rise of the understanding that its source of legitimacy lies in public confidence.

\section{Arendt's Supreme Court: Authority without Power}

Arendt believed that one of the chief reasons for the success of American democracy is that the Supreme Court has authority but is powerless (Arendt 1965, 200). It "was especially designed for the purpose of authority." (Arendt 1965, 199).

In Arendt's terms, legitimate power resides in the people (Arendt 1965, 179), while the "hallmark" of authority, "is unquestioning recognition by those who are asked to obey; neither coercion nor persuasion are needed." (Arendt 1970, 45). Arendt's description of authority captures the traits involved in obeying an expert, such as a doctor. In cases of expert advice, we indeed obey without coercion and sometimes even without persuasion (Arendt, 1965, 91). 
Arendt is not shy in characterizing authority as a hierarchal relationship and writes that "[a]uthority...is incompatible with persuasion, which presupposes equality and works through a process of argumentation... Against the egalitarian order of persuasion stands the authoritarian [or authority-based] order, which is always hierarchical.” (Arendt 1958a, 92-93).

By closely reading What is Authority?, we can detect that Arendt explicitly writes on expertise as the basis for an authority-based relationship. After noting that "[n]owhere else has Greek thinking so closely approached the concept of authority as in Plato's Republic," Arendt discusses several examples that Plato brings to "models of relations". One of these examples is the "physician and the patient" and Arendt notes that "[i]n all these instances either expert knowledge commands confidence so that neither force nor persuasion are necessary to obtain compliance..." (Arendt 1958a, 108. See also at 116). In a later text, Arendt gives another example of a relationship of authority: the relationship between a teacher and a pupil (Arendt 1970, 144). This relationship may also be characterized as based on expertise.

According to Arendt, while the Founders of the American Republic wished to imitate ancient Rome, in constructing the Court they did not imitate the Roman office of censorship, arguably the functional equivalent. Unlike the Justices who are appointed by elected representatives, the censor was elected by the Centuriate Assembly for a limited period of time. In Arendt's terms, censores held power because their source of legitimacy was public support (Arendt 1965, 200; Volk 2015, 183-85). This was not the model the Founders had in mind for the Court, as Arendt concludes: "[i]nstitutionally, it is lack of power, combined with permanence of office, which signals that the true seat of authority in the American Republic is the Supreme Court." (Arendt 1965, 200). According to Arendt, the Court does not rely on the people as its source of legitimacy but on its expert ability to decipher the Constitution. This interpretative ability is what makes the Court worthy of the unquestioning respect awarded to those who hold authority, such as experts (Goldoni \& McCorkindale 2013, 119, 126). Therefore, when she writes that "[a]ll political institutions are manifestations and materializations of power; they petrify and decay as soon as the living power of the people ceases to uphold them," (Arendt $1970,41)$ the emphasis should be put, in order to understand her view of the Court, on the phrase "political institutions." Arendt does not see the Court as a political institution but as an expert.

In order to fulfil its role as an expert, the Court has to interpret the Constitution according to its expert legal knowledge (Arendt 1965, 199; on Arendt's view of lawyers as experts see 
Arendt 1965, 237; Scheuerman 1997, 161; Klabbers 2007, 22). This is a legal function, in contrast to the political function of the equivalent institution in Rome that held authority, the Roman Senate (Arendt 1965, 199-200). But the Senate is also an expert, as Arendt adopts the idea that the Roman Senate was akin to a council of elders giving advice to children (Arendt 1958a, 122-23). The elders' expertise is in the foundations of Rome (Arendt 1958a, 121-24). As we shall see, Arendt also saw the Court as deriving it expertise from understanding American foundational moment. In view of all of these analogies between the Court and the Roman Senate, it is no wonder then that for Arendt the Roman Senate resembles "Montesquieu's judiciary branch of government, whose power he called 'somehow nil'...and which nevertheless constitutes the highest authority in constitutional governments." (Arendt 1958a, 122).

3. Arendt's Reading of The Federalist No. 78 vs. The Current "Reading" of The Federalist No. 78

Arendt' view of the Court's source of legitimacy corresponds well with Alexander Hamilton's The Federalist No. 78. Hamilton famously wrote that " $[\mathrm{t}]$ he judiciary on the contrary has no influence over either the sword or the purse. . . It may truly be said to have neither Force nor Will, but merely judgment; and must ultimately depend upon the aid of the executive arm even for the efficacy of its judgments." (Hamilton, Madison, Jay 2009, 392). According to Hamilton, the government's support, essential for the efficacy of the Court's rulings, is acquired because the executive branch acknowledges the value of the Court's judgment and not because the Court holds public support. Even if the Court makes a judgment that is contrary to popular opinion or to the government's interests, the government will still enforce the judgment, in the same way a patient complies with a treatment that causes pain because it is recommended by her doctor. Like the doctor, the Court, speaks in the name of expertise. Hamilton based the Court's legitimacy "merely" on its legal expertise; not on public support for the Court (Bassok 2013, 373-75).

Arendt quotes in agreement Hamilton's dictum and adds "[i]n other words, its very authority made it unfit to power, just as, conversely, the very power of the legislature made the [US] Senate unfit to extract authority." (Arendt 1965, 200). According to Arendt, the success of the US is that law and power have "clearly recognized different origins, different legitimations, and different spheres of application." (Arendt 1965, 166). The Court's legal knowledge and 
detachment from public support made it suitable for legitimacy based on expertise ("authority"), while the American Senate's nature as an elected body made it suitable for legitimacy based on public support ("power") and unfit to extract authority.

In The Federalist No. 81, Hamilton objected that the final appeal in cases will be to the branch of the legislature (the Senate) in a manner that will be equivalent to the British House of Lords that had held judicial power of "last resort." Hamilton explains that judges as "men selected for their knowledge of the laws, acquired by long and laborious study", rather than elected representatives, are better equipped to ensure that the Constitution would not be breached (Hamilton, Madison, Jay 2009, 408). Arendt's position on the difference between the Roman Senate and the American Senate represents the exact same logic. The former was not elected and thus had authority. In this regard, its equivalent in the US is the judiciary. The American Senate may share the same name as the Roman senate since the word "Senate" became "dear" to the American founders. But Arendt notes that they have "very little in common." (Arendt 1965, 199200). The "men" elected to the American Senate do not necessarily hold "wisdom," even though the process of discussing opinions at the Senate may in the end produce wise decisions (Arendt 1965, 227; Volk 2015, 206).

In the US a development in understanding judicial legitimacy has occurred in recent years, a development best captured in the manner in which Hamilton's dictum is currently paraphrased (Bassok 2016). In 2012 Pamela Karlan ends her Harvard Foreword titled Democracy and Disdain by saying:

"Alexander Hamilton was slightly off base when he wrote that the judiciary has 'neither Force nor will but merely judgment; and must ultimately depend upon the aid of the executive arm even for the efficacy of its judgments.' The judiciary must ultimately depend on the people." (Karlan 2012, 71).

In other words, Karlan views public support as the Court's source of legitimacy. Even if the Court lacks expertise, as long as it holds public support, it will function properly.

Speaking in the name of the people has been a potent symbol over the course of the United States political history (Frank 2010, 4-5). Yet, until the invention of public opinion polls, the elected institutions had monopoly over this source of legitimacy (Bassok 2013, 156-59). No wonder then that Hamilton's un-paraphrased dictum - attributing the Court's legitimacy to its expertise - reigned supreme (Bassok 2016, 574-77). Elsewhere I discuss at length the invention 
of public opinion polls as the tool that enabled this important and dramatic development in the understanding of the Court's source of legitimacy (Bassok 2016; Bassok 2013). For the purposes of this Article that focuses on the dangers Arendt would have seen in such a development, it is sufficient to say that today it is a truism to argue that the Court must have public support to function properly. Both conservative and progressive justices share the idea that the Court's source of legitimacy rests on its enduring public support (Planned Parenthood v. Casey, 505 U.S. 833 [1992], at 865; Bassok 2011, 258-63; Bassok 2016). This idea has become so powerful in American constitutional discourse that it has become commonsensical or natural (Bassok 2011, 240-41). Most jurists do not even notice, as Karlan did, that they are paraphrasing what Hamilton wrote in The Federalist No. 78 to fit this controlling understanding; they simply read Hamilton as confirming the controlling paradigm. For modern American readers of Hamilton, the crucial question is whether the Court holds sociological legitimacy, that is, whether the public supports it. For Hamilton and Arendt, the question was whether the Court has judgment; whether it holds expertise. In the next section, I will address the special expertise Arendt attributed to the Court and how it ensures the authority of the Constitution.

\section{Arendt as an Identity Originalist}

After toppling the king, the French revolutionaries deified the will of the people, which as a result served both as the source of power and the source of law. Imagining popular sovereignty “in God's own image" created the danger of a sovereign that can sweep away all legal and normative constraints "like a hurricane” (Arendt 1965, 181-86; Kalyvas 2008, 215-17). In other words, all the foundations, including those that the Revolution professed, could be changed as long as the will of the people supported such a change (Arendt 1965, 167, 183-84; Arendt 1958a, 110; Kalyvas 2008, 234-35). In the name of the will of the people - the higher law of the revolution - any law could be changed, including laws that were born with the revolution (Arendt 1965, 183). The sovereign, after all, is bound by no universal law and acknowledges nothing superior to itself (Arendt 1979, 230; Kalyvas 2008, 219-20). In Arendt's view, this kind of unbound popular will is the recipe for a failed constitutional order and catastrophic results, as the aftermath of the French Revolution demonstrates. 
The success of the American Revolution is the division between law and power. In the US, from the outset, "[t]he seat of power to them was the people, but the source of law was to become the Constitution..." (Arendt 1965, 157-59). The revolution succeeded in putting law above men by creating a constitution that has been worshiped from a very early stage because of its connection to the founding moment (Arendt 1965, 183-85, 198-199). In other words, both the American and French revolutions held in common "the conviction that source and origin of legitimate political power resides in the people.” (Arendt 1965, 179). However, the French Revolution failed to realize the need to create an authority that is not based on power coming from the people. A stable governmental structure cannot be built on this "quicksand" (Arendt 1965, 163; Kalyvas 2008, 219-20). The American "reverent awe" to the act of the founding ensured that the Constitution was not dependent on the current will of the people (Arendt 1965, 204). Subsequently, continuing attempts in the name of the ever-changing "subjective state of mind" of the people to dismantle the foundations of the revolution were avoided, as long as these foundations were put in constitutional forms (Arendt 1965, 157; Scheuerman 1997, 151, 154).

According to Arendt, the American Constitution's endurance over time was achieved thanks to the Court's continuing interpretation of the Constitution that ensured its connection to the founding revolution. In Arendt's words - supposedly quoting Woodrow Wilson ${ }^{1}$ - the Court has functioned as "a kind of Constitutional Assembly in continuous session." (Arendt 1965, 200). Arendt argues that, as in Rome, the continuing connection to the founding moment is the source of authority: first, the Constitution's authority, and subsequently also the Court's (Arendt 1965, 202-03). For her, the founding is the "fountain of authority" (Arendt 1965, 204), the Constitution bears within itself the spirit of the founding, and the Court's role is to serve as the living voice of that origin (Arendt 1965, 231-32; Gottsegen 1994, 124). Arendt is even tempted to predict that "the authority of the republic will be safe and intact as long as the act itself, the beginning as such, is remembered whenever constitutional questions in the narrower sense of the word come into play." (Arendt 1965, 204).

In order for the Court to fulfil its role of connecting current America to the founding, Arendt offers a mechanism that is very similar to an interpretative system that today we call “originalism" (cf. Burns, 167, 171, 174-75). But Arendt's originalism is of a special kind. Through an "origin-oriented" interpretative theory, Arendt wants to ensure a thread connecting

\footnotetext{
${ }^{1}$ As I elaborate below, Arendt's quote is inaccurate.
} 
original American identity and current American identity. I dub this sub-type of originalism: identity originalism (Bassok 2015a, 297-302). In the process of constitutional interpretation, originalists give a central place to the way the Constitution was understood originally, during the founding generation. However, some of them reject the idea that the Constitution is an identity manifesto and view originalism as merely a technique to interpret a legal text (Solum 2011, 74; McGinnis \& Rappaport 2012: 750); others accept the Constitution's central role in American identity but reject the notion that the founding plays such a central role in constructing current American identity (Balkin 2011, 74-81). For identity originalists, the Constitution is the focal point of American identity and originalism is the roadmap to American identity. According to identity originalists, by reading the Constitution according to its original meaning, the Court ensures the continuing fidelity to the original American identity (Bassok 2015a, 297-98, 302). To fulfil this role, identity originalists maintain that the Justices hold expertise in constitutional history and thus, in essence, the Justices are experts in American original identity (Berger 1977, $8-9,18)$.

Arendt's identity originalism fits well with her analogy between the Court and the Roman Senate since Arendt saw the Roman Senators as also guided by Rome's past in their role of making sure that Rome's law are in line with the city's founding principles (Goldoni \& McCorkindale 2013, 120-21). Arendt explains that the Senate's authority in Rome is to be understood according to the origins of the word "authority" which point to the notion of augment: the act of enlarging a foundation (Lara 2013, 105, 108). Similarly, the Court's interpretative authority is derived from its role to conserve, "increase and enlarge" the most concrete achievement of the original act of foundation (Arendt 1965, 201; Scheuerman 1997, 158; Gottsegen 1994, 124). The Court conserves the link to the original understanding of the founding moment; ensuring that the original spirit of the Revolution continues to serve as a central part of American existence. In the absence of frequent constitutional amendments, the main way to reiterate the act of foundation is through the Court's originalist constitutional interpretation (Arendt 1965, 202).

Writing at the high point of the Warren Court, Arendt notes on the Court's failure to fulfil this promise of "remembering the revolutionary spirit" (Arendt 1965, 231-32, 239). In Arendt's view, adopting identity originalism does not create a problem of being bound to that dead hand 
of the past since the current loyalty of the people to the Constitution is to be understood in terms of choosing to bind "themselves back to a beginning." (Arendt 1965, 198).

Detecting the connection Arendt creates between the revolutionary "fountain of authority," the Constitution, and the Court's interpretative method answers queries in scholarly literature regrading her supposedly disregard of the question of ultimate interpretative authority (Frank 2010, 54-55). Arendt did not neglect this question. Rather, she believed that the Court was entrusted with the role of ensuring the connection to the founding constituting moment. True, this view does not sit well with her position favoring extra-institutional politics (Arendt 1958b, 230). Arendt's latter position better fits a system of weak judicial review (Volk 2015, 246-48) combined with popular constitutionalism that takes "the people themselves to be the ultimate authority on questions of legal interpretation." (Frank 2010, 54, 57-58). Yet, as explained above, this is not Arendt's position with regard to the American Supreme Court. Her position regarding the American Court may be partly a result of her doubts of the American public's ability to maintain alive the spirit of the revolution in view of their impoverished political experience in times of "regular" politics (Arendt 1975; Sitton 1987, 81-82). This reading of American political reality is part of her general view of the modern state as going through a process of de-politicization (Arendt 1958b, 28-33; Kalyvas 2008, 208-09). The current modern public arena can produce only "moods of the masses" rather than proper opinion formation, as could be achieved according to her plan of council democracy (Arendt 1965, 221; Sitton 1987, 81-82, 93). Arendt thus creates a distinction between "public opinion" in the sense of uneducated public moods and public opinions which are the result of a process of open discussion and public debate (Arendt 1965, 268-69; Sitton 1987, 85).

Arendt does not deny that the Constitution can be approached "from many different angles, and upon which one could impose many different interpretations...," but the Court's interpretations are not to be guided by the will of the people (Arendt 1965, 157). The Constitution is "subject to the will of a majority" no more than a "building is...subject to the will of its inhabitants." (Arendt 1965, 164). She summarizes that the Constitution "has remained a tangible worldly entity of greater durability than elections or public-opinion polls." (Arendt 1965, 157). Without the Constitution as an Archimedean point of authority, without the Court using identity originalism to connect current America to its founding, a new founding may occur 
whenever there is a strong enough difference of opinion. A revolution would be lurking at every corner.

Public opinion must be kept at bay according to Arendt and the Court holds a key role in ensuring this result. But what is the problem with a court that views its legitimacy as based on public support without necessarily following public opinion in concrete cases? Arendt's answer to this question is not explicit. Her writings make very clear the inherent contradiction between the Constitution as an Archimedean point of authority and the hurricane of public opinion. My analysis explained the role of the Court in maintaining the connection between the Constitution and the founding moment and thus ensuring the Constitution's ability to maintain its authority. By explaining Arendt's reading of Hamilton's The Federalist No. 78 I was also able to decipher Arendt's saying that the Court is the true seat of authority but unfit to power. While Arendt's intuition on the Court being unfit to power is very appealing in view of this analysis, I argue that with more interpretative work another layer can be exposed in Arendt's writing, a layer that explains the danger of a Court holding power.

\section{The Danger Lurking}

In her writings, Arendt directly deals with two dangers that threaten the Court's ability to fulfil its function (Goldoni \& McCorkindale 2013, 125-31). First, her concern that the Court was exceeding its role as the interpreter of the Constitution in the context of the school desegregation decisions (Arendt 1958-59). Second, her concern that the Court cannot practice its authority in crucial political issues such as the Vietnam War (Arendt 1972, 99-101). While these dangers were of the Court not fulfilling or exceeding its authoritative role, the current danger facing the Court is of a different kind. The current danger - as expressed in the shift in reading The Federalist No. 78 - is of a court with power i.e., a court that switches its understanding of its source of legitimacy from expertise to public support. Since Gallup began tracking public support for the Court and its decisions in a systematic way only during the 1960 (Marshall 2008, $1-2,29,77)$, Arendt was unable to detect the influence of measuring public support for the Court on its understanding of judicial legitimacy. Yet, while she did not address this danger directly, we can distill her position towards it from her view of the Court's proper role.

Arendt agrees that "public opinion as the greatest force ruling an egalitarian democratic society" is one of the few principles that had survived from the principles of the Revolution, 
"after the revolutionary spirit had been forgotten." (Arendt 1965, 221). She stresses that "in the last analysis," all authority rests on opinion in the sense that every regime requires public confidence (Arendt 1965, 230). Of course, such a statement does not mean that each separate institution requires public confidence. As Owen Fiss explained in a democracy "consent is not granted separately to individual institutions. It extends to the system of governance as a whole. Although the legitimacy of the system depends on the people's consent, an institution within the system does not depend on popular consent.” (Fiss 1985, 43-44; see also Fiss 1979, 38).

Arendt was very aware of the danger in democracy's "inclination to be swayed by public opinion and mass sentiments." (Arendt 1965, 225). In view of this danger, she quotes a letter by Hamilton in which he speaks of "a permanent body [that] can check the imprudence of democracy." (Arendt 1965, 225). Arendt admits that "[ $t]$ he institution originally designed to guard against rule by public opinion or democracy was the Senate." (Arendt 1965, 226). Yet, the Supreme Court has become in practice the "lasting institution for judgment" that offers "judicial control" over public opinion (Arendt 1965, 228-29).

Arendt fears that a court guided by the logic of public opinion would fail to ensure the stability of the foundation i.e., of the Constitution. After all, the Constitution was created as a "written document, an endurable objective thing...never a subjective state of mind, like the will." (Arendt 1965, 157). It was designed to remain "a tangible worldly entity of greater durability than elections or opinion polls." (Arendt 1965, 157). The Constitution has an inbuilt amendment mechanism that makes it relatively immune to public opinion except on rare occasions. ${ }^{2}$ If the Court becomes an agent of public opinion, this entire structure is put in jeopardy.

Analyzing a point Arendt made in her short and controversial article Reflection on Little Rock further exposes the contradiction Arendt saw between authority based on expertise and public opinion. In this article, written following the Supreme Court decision to desegregate schools in the South, Arendt argues that the Court was mistaken in interfering in the private and social realm (Arendt 1958-59, 242). She writes that " $[\mathrm{t}]$ o force parents to send their children to an integrated school against their will means to deprive them of rights which clearly belong to them in all free societies - the private right over their children and the social right to free association." (Arendt 1958-59, 242). The details of Arendt's controversial position towards de-

\footnotetext{
${ }^{2}$ For reasons of simplicity I avoid discussing the issue of constitutional amendment outside of Article V. However, even those, such as Bruce Ackerman, who espouse this road for amending the Constitution, do put limitations on public will that are akin to those put by the formal amendment process. See Bassok 2015a, 307-11.
} 
segregation are not the focus here. I would like to focus on Arendt's argument that the Court's interference affected the relationship between children and their teachers and parents, since as explained above, this type of relationship demonstrated for Arendt an authority-type relationship. Arendt writes under the plausible premise that in the South in that period, white parents supported segregation. Hence, she concludes that "[t]he conflict between a segregated home and a desegregated school, between family prejudice and school demands, abolishes at one stroke both the teachers' and the parents' authority, replacing it with the rule of public opinion among children who have neither the ability nor the right to establish a public opinion of their own." (Arendt 1958-59, 243). If we make an analogy between the Court's authority and the teachers or parents' authority, we can conclude that if the Court's authority based on expertise erodes, we are doomed to the control of public opinion.

Of the danger of public opinion controlling an institution with authority we can learn from a reference Arendt makes to Kant in her essay What is Authority? Discussing Plato's philosopher-king figure as an example closely approaching the concept of authority (Arendt 1958a, 106-07), Arendt notes that "this combination of reason and rule implied a danger to philosophy as well" and not merely to the political realm (Arendt 1958a, 107). The philosopherking's attempt to rule according to reason presents a danger to reason. But what is this danger? Arendt notes that Kant's discussion of Plato is the only reference to this danger. She proceed to quote Kant, "[i]t is not to be expected that kings philosophize or that philosophers become kings, nor is it to be desired, because the possession of power corrupts the free judgment of reason inevitably." (Arendt 1958a, 107). In other words, we can expect the legal language to be corrupted if the Court understands its source of legitimacy to lie in power (public support).

In order to better understand this point, I will use an analogy frequently made between judges and doctors, and medicine and law (e.g., Kahn 1997, 126; Richman 2009, 1731). In recent years medicine has encountered a challenge to its autonomy as a distinct language of expertise, with the introduction of a metric measuring doctors' performance based on patients' opinions (Schoenfelder 2012). Over the last two decades in the US, measurements of "patient care experience" or "patient satisfaction" have become more and more prevalent in many hospitals and organizations (Price 2014, 523-24). Some of these programs even give financial bonuses based on the level of patient satisfaction (Schoenfelder 2012; Price 2014, 523). 
The results of the entrance of public opinion polls into the medical profession are a mixed bag and highly disputed. A study from 2012 titled The Cost of Satisfaction summarizes several studies conducted following the introduction of this metric, noting that "[s]atisfied patients are more adherent to physician recommendations and more loyal to physicians, but research suggests a tenuous link between patient satisfaction and health care quality and outcomes." (Fenton 2012, 405. Cf. Price 2014, 534). The study goes further than its literature review and, based on a national sample, shows that the highest level of patient satisfaction is associated with greater prescription drug costs and overall health care expenditure. Furthermore, it is associated with higher overall mortality compared to those with the lowest levels of satisfaction (Fenton et al. 2012, 405-09).

In a study from 1997, doctors prescribed antibiotics to patients presenting acute respiratory illness, even though in many of these cases they judged the antibiotics to be unnecessary. The study suggests that over-prescription is a result of doctors taking into account their understanding of patients' expectations and satisfaction (Holmes 1997, 1211-1214). Another study examined the imaging exams prescribed by physicians for patients with uncomplicated acute lower back pain. One central conclusion was that "patients cared for by physicians exposed to incentives based on patient satisfaction received more rapid and advanced imaging" even though such an examination "may not benefit patients and may result in harm." (Pham 2009, 972, 977).

No doubt, from time immemorial, patients' assessments of doctors were based not only on assessing their professional expertise. Patients were also interested in their physicians' ability to communicate and behave in a caring fashion. Yet, the ability to measure these assessments in fungible units that allow for a comparison between doctors has corrupting effects on the language of medicine. In Arendtian terms, doctors' attempt to ensure their power leads to the corruption of their language of medical expertise. Similarly, courts and politicians spoke of public confidence in courts well before the invention of public opinion polls (Bassok 2013, 15859). Yet, the ability to measure public opinion has the potential to lead to a court that views its source of legitimacy in the people; in Arendtian terms, this is a court with power. Such a court in may corrupt law as a language of expertise.

The language of law has aspired to function as a language of expertise. In languages of expertise, the question of which argument is proper or legitimate cannot be determined by 
popular will or by popular use of an argument. Expert knowledge must be determined by the community of experts according to their rules of their discipline (Post 2012, xii-xiv, 8, 29-32). The entry into legal language through the legislation process is dependent on popular will, but the separation of law and politics after the legislative process is aimed to create an autonomous field for a language of expertise (Bassok, 2015b). In this manner, the legal language creates a space of argumentation controlled by experts rather than by public opinion. In Arendtian terms this is the language of authority rather than a language of power. But just as the philosopher king would corrupt reason if given a chance to rule, a court guided by power would corrupt the systematic-rational character of the legal language (Volk 2015, 111-24).

\section{Competing Interpretations of Arendt's Writings on the Court}

Before concluding, I would like to discuss several conflicting interpretations of Arendt's analysis of the American Supreme Court. As opposed to Jean Cohen and Andrew Arato's argument, Arendt did not suggest that the Court functions as "a constituent assembly" that rewrites the constitution as a "constitution of judges." (Arato and Cohen 2009, 317). While I have great respect for the work done by Cohen and Arato over the years, their reading of Arendt on this point is based on two mistakes. First, Arato and Cohen misquote Arendt's reference to Wilson. They write that she is quoting Wilson depicting the Court as "a constituent assembly in permanent session." They add their reading of this quote to mean that the Court is "also an organ capable of usurping sovereignty." (Arato and Cohen 2009, 317). The quote is not what Wilson said and not how Arendt quoted him. Based on a quote from Corwin, Arendt quotes Wilson to be saying that the Court is "a kind of Constitutional Assembly in continuous session." 3 The difference between a "constituent assembly" and a "constitutional assembly" is important. ${ }^{4}$ A continuous session of the former means an ongoing project of redefining the polity's foundations

\footnotetext{
${ }^{3}$ Arendt also misquotes the quote that Corwin brings. Corwin writes that "Indeed, the Supreme Court by its decision interpreting the Constitution, constantly alters the practical effect and application thereof. As Woodrow Wilson aptly put it, the Supreme Court is 'a kind of Constitutional Convention in continuous session."' (Corwin 1958, 5). Clearly, Corwin did not refer to Wilson to insinuate that the Court redefines the constitutive features of the American Republic. Rather, the Court merely interprets them in the application of the Constitution.

${ }^{4}$ Arato and Cohen partly fix the quote in a later edition of their article. Although they still speak of Arendt as a supporter of "a constitution of judges," now Arendt is quoted as quoting Wilson saying that the Court is "a kind of constitutional assembly in permanent session." (Arato and Cohen 2010, 161). While the first part of the quote is now fixed, the second part is still mistaken. Arendt wrote: "continuous session."
} 
(Kalyvas 2008, 203, 229-30). ${ }^{5}$ This would very much contradict Arendt's view of the American Constitution and the Court as measures of permanence and stability (Arendt 1965, 228-29; Scheuerman 1997, 158). A “constituent assembly" predates and precedes the constitutional order (Arendt 1958b, 199). For these reasons, Arendt did not see the Court as a constituent assembly capable of redefining the principles constitutive of the American Republic. Rather, she saw it as continuing the constitutional endeavor as defined by the revolutionary spirit. She speaks of a "continuous session" - rather than of a "permanent session" as Cohen and Arato attribute to her - since she views the Court as protecting and building on the original act of foundation (Scheuerman 1997, 158).

Second, Arendt speaks of the Court as "a kind of Constitutional Assembly" (my emphasis) when she attempts to explain the Court's authority or special status in connection to the founding. This depiction is focused on the Court's source of authority rather than its function, as Cohen and Arato read it. As for the Court's function, according to Arendt, the Court should interpret the Constitution in a manner that ensures a continuing thread from the founding era and not re-write the Constitution (as the phrase "constitution of judges" used by Cohen and Arato implies).

I also partly differ from William Scheuerman's reading of Arendt on this point. After describing Arendt's view of the Court's authority as "hierarchical" rather than based on persuasion, Scheuerman explains that "[i]t is difficult to imagine what status such a conception of authority can rightfully possess in a modem, disenchanted democratic polity: particularly in a democracy, only argumentation and discursive 'persuasion' can legitimately justify the exercise of state power." (Scheuerman 1997, 159). Scheuerman adds that the Court can thus be viewed as asserting traditional forms of political domination (Scheuerman 1997, 159). Arendt would argue that Scheuerman simply fails to understand the essence of authority that is based on expertise. The sign of expert authority is what Scheuerman views as illegitimate domination. Arendt admits that the meaning of authority as she uses the word "has vanished from the modern world." (Arendt 1958, 91). She writes that "the old time-honored metaphors and models for authoritarian

\footnotetext{
${ }^{5}$ It is unfortunate that Klyvas, who emphasizes the distinction between "constitutional" and "constituent" power, reads Arendt's quote of Wilson as saying that the "the Court is a kind of continuous constituent power" in a manner similar to Cohen and Arato's misreading (Kalyvas 2008, 279). This leads him to attribute to Arendt inconsistencies that do not exist in her analysis.
} 
relations," such as that between teachers and pupils, "have lost their plausibility." (Arendt 1958, 92).

Scheuerman further argues that On Revolution presents a picture in which "the ongoing 'constitutional conversation' of the Supreme Court represents an augmentation of the 'mutual deliberation' basic to the act of founding itself," whereas in What is Authority? Arendt presents authority as "incompatible with persuasion." (Scheuerman 1997, 158). As explained above, Arendt's model of authority does not change in On Revolution, as evident from the teacher-pupil example that adheres to her earlier writings on the authority (see also Arendt 1965, 279).

Christian Volk reads Arendt through the prism of "dehierarchisation" and views the Court as part of such an apparatus (Volk 2015, 159, 177-80, 214-15, 225, 229, 244-48). This reading attempts to fit Arendt to current trends in understanding courts as institutions that enhances deliberative democracy. In his view, rather than being autorotative experts, the Court is part of an ongoing constitutional interpretative discourse with other institutions, as well as with the people themselves (Kramer 2004). Whether this view reflects reality or not, it is a misreading of Arendt as it fails to take seriously her hierarchical understanding of authority and her emphasis that the Court was created to hold authority. Moreover, saying that the Court's authority relies on its connection to the founding moment, and in that sense it functions as "a kind of Constitutional Assembly," does not mean that its current function includes "mutual deliberation" with the people. The Court does not recreate the founding moment in its work by recreating a "mutual deliberation" with the people. Commitment to the founding moment in terms of the Court's interpretative theory does not mean that the Court needs to recreate a deliberative process in its practice because of the mutual deliberation that arguably was prevalent during the founding era. Adhering to identity originalism as an interpretative system does not entail an adoption (and in some ways it even contradicts) of the model of a dialogue between the Court and the people of here and now. Similarly, as opposed to Scheuerman's claim (Scheuerman 1997, 160), Arendt's dismay at "[t]he constitution of experts under which Europe came to live after the First World War" (Arendt 1965, 144) does not contradict giving the Court the authority to keep the connection to the founding based on its interpretative expertise. The notion of "constitution of experts" in Europe after the First World War expressed the understanding that the failure of constitutions to guard democracy before the second world, especially in Weimar Germany, was the result of their creation by experts without the 
involvement and the support of the public (Feuchtwanger 1993, 39; Arendt 1965, 144-45).

Arendt's whole point is that in the US, the Court's role is to connect the present reading of the Constitution to its founding moment, a moment that captures the will of the people. While the Court's role in not to re-write the Constitution and to make it a constitution of judges or experts, the Court is relying on its expertise when interpreting the Constitution to connect its present interpretation to the founding moment.

\section{Conclusion}

The picture Arendt dreaded in her insistence on the need to separate power from authority was one in which the will of the people roams with no restrains and is able to define and redefine the foundations. This was her depiction of France under Robespierre and to some extent her understanding of Germany in the early years under Hitler (Burns 1987, 175). In common with many of her Jewish contemporaries who experienced the collapse of the Weimar Republic, Arendt was preoccupied by a scenario in which a popular elected president would reconstitute the state's foundations, speaking in the name of an allegedly superior popular mandate as a source of legitimacy (Arato and Cohen 2009, 313; Volk 2015, 167-72). Arendt was part of a general tendency of German state theory to focus on the question of political order (Volk 2015, 15-16, 249). Yet Arendt feared from a specific danger of power gaining authority.

The picture I have presented in this article is of judicial authority gaining power. The Court - which speaks in the name of the constitutional foundations - is now understood to rely on public support as its source of legitimacy. Rather than having "merely expertise," it holds "public confidence." This was not a picture Arendt envisioned, since the regular measurement of public support for the Court in opinion polls that enabled such a shift had just begun at the time she was writing. At first glance, this development seems not only not dangerous but perhaps even positive. The least dangerous branch had just become stronger. Yet probing Arendt's argument exposes a danger: the corruption of the language of authority once power affects the Court. Measuring doctors' performance by patient satisfaction demonstrated the danger of corrupting the medical discipline. Similarly, the legal language of expertise is in danger of corruption once the Court understands its legitimacy to be based on public confidence. 


\section{References}

Arato, A. and J. Cohen. 2009. Banishing the Sovereign? Internal and External Sovereignty in Arendt. Constellations 16: 307-330.

Arato, A. and J. Cohen. 2010. Banishing the Sovereign? Internal and External Sovereignty in Arendt. In Politics in Dark Times. 137-171. Ed. Seyla Benhabib. Cambridge University Press: Cambridge, UK.

Arendt, H. 1958a.What is Authority? In Between Past and Present: Eight Exercises in Political Thought. (1977). Penguin: NY.

Arendt, H. 1958b. The Human Condition. Chicago University Press: Chicago.

Arednt, H. 1958-59. Reflections on Little Rock. In The Portable Hannah Arendt (2000). 231-46. Ed. Peter Baehr. Penguin: NY.

Arendt, H. 1965. On Revolution. Penguin: London, UK.

Arednt, H. 1970. On Violence. HBJ: San Diego.

Arendt, H. 1972. Civil Disobedience. In Crises of the Republic (1972). New York: Harvest Book.

Arednt, H. 1975. Home to Roost. In Responsibility and Judgment (2003). New York: Schocken. Arednt, H. 1979. The Origins of Totalitarianism. New York: Harvest Book.

Balkin, Jack M. 2011. Living Originalism. Cambridge, MA: Belknap Press of Harvard University Press.

Bassok, O. 2011. The Sociological-Legitimacy Difficulty. Journal of Law \& Politics 26: 239-72. Bassok, O. 2013. The Supreme Court's New Source of Legitimacy. University of Pennsylvania Journal of Constitutional Law 16: 153-198.

Bassok, O. 2015a. Interpretative theories as roadmaps to constitutional identity: The case of the United States. Global Constitutionalism 4: 289-327.

Bassok, O. 2015b. Constitutional Law: A Language of Expertise?. The Georgetown Law Journal Online 103: 66-77.

Bassok, O. 2016. The Supreme Court at the Bar of Public Opinion Polls. Constellations 23: 57384.

Berger, R. 1977. Government by Judiciary: The Transformation of the Fourteenth Amendment. Cambridge, MA: Harvard University Press.

Breyer, S. 2010. Making Our Democracy Work: a Judge's View. Alfred A. Knopf: New York. Burns, R. 1987. Hannah Arendt's Constitutional Thought. In Amor Mundi: Explorations in the Faith and Thought of Hannah Arendt, 157-85. Ed. J.W. Bernauer. Martinus Nighoff Publishers: Hingham, MA.

Corwin, E.S. 1958. The Constitution and What It Means Today. Princeton University Press:

Princeton, N.J.

Fenton, J.J., A.F. Jerant, K.D. Bertakis and P. Franks. 2012. The Cost of Satisfaction: A National Study of Patient Satisfaction, Health Care Utilization, Expenditures, and Mortality. 172 Archives of Internal Medicine 172: 405-11.

Feuchtwanger, Edgar J. 1993. From Weimar to Hitler: Germany, 1918-33. Macmillan: Basingstoke.

Fiss, O.M. 1979. The Supreme Court, 1978 Term, Foreword: The Forms of Justice. Harvard Law Review 93: 1-58.

Fiss, O.M. 1985. Two Models of Adjudication. In How Does the Constitution Secure Rights?, 36-49. Eds. R.A. Goldwin and W. A. Schambra. American Enterprise Institute for Public Policy Research: Washington. 
Frank, J. 2010. Constituent Moments. Duke University Press: Durham and London.

Gibson, J. L., G. Caldeira, and V.A. Baird. 1998. On the Legitimacy of National High Courts. American Political Science Review 92: 343-58.

Goldoni, M. C. McCorkingdale. 2013. The Role of the Supreme Court in Hannah Arendt's Political Constitution. In Hannah Arendt and the Law, 117-32. Eds. M. Goldoni and C. McCorkingdale. Hart Press: Oxford.

Gottsegen, M.G. 1994. The Political Thought of Hannah Arendt. State University of New York Press: Albany, N.Y.

Hamilton A., J. Madison, J. Jay. 2009. The Federalist Papers. Ed. Ian Shapiro. Yale University Press: New Haven, CT.

Holmes, W., M.J., Britten N.M.R. 1997. Influence of Patients' Expectations on Antibiotic Management of Acute Lower Respiratory Tract Illness in General Practice: Questionnaire Study, BMJ. 315:1211-14.

Kahn, P.W. 1997. The Reign of Law: Marbury v. Madison and the construction of America. Yale University Press: New Haven.

Kalyvas, A. 2008. Democracy and the Politics of the Extraordinary: Max Weber, Carl Schmitt and Hannah Arendt. Cambridge University Press: Cambridge.

Karlan, P.S. 2012. The Supreme Court, 2011 Term, Foreword: Democracy and Disdain. Harvard Law Review 126: 1-71.

Klabbers, J. 2007. Possible Islands of Predictability: The Legal Thought of Hannah Arendt. Leiden Journal of international Law 20: 1-23.

Kramer, L.D. 2004. The People Themselves: Popular Constitutionalism and Judicial Review. Oxford University Press: New York.

Lara, M.P. 2013. The disclosure of politics: struggles over the semantics of secularization. Columbia University Press: New York.

Marshall, T.R. 2008. Public Opinion and the Rehnquist Court. State University of New York Press: Albany, N.Y.

McGinnis, John O. \& Rappaport, Michael. 2012. "The Abstract Meaning Fallacy." University of Illinois Law Review 2012: 737-82.

Pham, HH., Landon, BE., Reschovsky, JD., Wu B., Schrag, D. 2009. Rapidity and Modality of Imaging for Acute Low Back Pain in Elderly Patients. Arch Intern Med. 169(10): 972-81.

Post, R.C. 2012. Democracy, Expertise, and Academic Freedom. Yale University Press: New Haven.

Price, R.A. et al. 2014. Examining the Role of Patient Experience Surveys in Measuring Health Care Quality. Med Care Res Rev. 71(5): 522-54.

Scheuerman, W.E. 1997. Revolutions and Constitutions: Hannah Arendt's Challenge to Carl Schmitt. Canadian Journal of Law and Jurisprudence 10:141-61.

Schoenfelder, T. 2012. Patient Satisfaction: A Valid Indicator for the Quality of Primary Care? Primary Health Care 2:1000e106.

Sitton, John F. 1987. Hannah Arendt's Argument for Council Democracy. Polity 20.1: 80-100.

Solum, Lawrence B. 2011. What Is Originalism? The Evolution of Contemporary Originalist

Theory. In Grant Huscroft \& Bradley W. Miller (eds.) The Challenge of Originalism. New York:

Cambridge University Press.

Richman, B. 2009. On Doctors and Judges. Duke Law Journal 58:1731-41.

Volk, C. 2015. Arendtian Constitutionalism: Law, Politics and the Order of Freedom. Hart Press: Oxford. 